\title{
Müş̧teri Değer Algısı ile Hedef Maliyet Arasındaki İlişkinin İncelenmesi: Bir Otel İşletmesi Örneği
}

\author{
DOI: 10.26466/opus.554110 \\ * \\ Nilgün Sanalan Bilici* - Volkan Tuncel ${ }^{* *}$ \\ * Dr. Ögr. Üyesi Atatürk Üniversitesi, Turizm Fakültesi, Erzurum/ Türkiye \\ E-Posta: nbilici@atauni.edu.tr \\ ORCID: 0000-0001-8318-7250 \\ ** Öğr. Gör. Bingöl Üniversitesi, Sosyal Bilimler Meslek Yüksekokulu, Bingöl/ Türkiye \\ E-Posta: volkantuncel44@gmail.com \\ ORCID: $\quad \underline{0000-0003-4772-5853}$
}

\section{Öz}

Satış fiyatının piyasa tarafından belirlendiğ günümüz rekabet ortamında işletmeler varlıklarını başarılı bir şekilde sürdürebilmeleri karlılıklarını artırmak için değiştirebilecekleri en önemli şey olan maliyetler üzerinde minimum seviyeyi yakalamaları gerekmektedir. Bu anlayışla birlikte müşteri değer algısının yönetilmesi işletme yönetiminin hedeflerine ulaşmasında önem arz etmektedir. Bu bağlamda yetersiz kalan geleneksel maliyet yönteminin yerine, müşteri istek ve beklentilerini karşılayacak maliyetlerin henüz gerçekleşmeden yönetilmesine olanak sağlayan hedef maliyet yöntemi uygulanmaktadır. Çalışmanın amacı; konaklama işletmelerinde müşteri değer algısı ve hedef maliyet arasındaki ilişki düzeyleri incelenerek, işletme hissedarları ve müşterilerinin memnuniyetini să̆lamak için konaklama işletmesi yöneticilerine alacakları yönetsel kararlarda katkı sağlamasıdır. Bu amaçla; Ardahan'da faaliyet gösteren bir konaklama işletmesi müşterilerine yönelik hazırlanan anket çalışması yüz yüze görüşme tekniği kullanılarak 363 müşteriye uygulanmıştır. Araştırma sonucuna göre; konaklama işletmesi hedeflediği maliyet seviyesine ulaşmak için müşteri değer algisını hedef maliyetleme sürecine dahil etmelidir. Bu doğrultuda, işletmenin hedeflemiş olduğu karlllık seviyesine ulaşması için hangi hizmet parçalarında maliyetlerin düşürüleceği ve hangi hizmet parçalarında işlevselliğin arttırılması gerektiği tespit edilmiştir.

Anahtar Kelimeler: Müşsteri Değer Algısı, Hedef Maliyet, Hedef Maliyet Endeksi. 


\title{
Investigation of the Relationship Between the Value Perception of Customer and Target Cost: Sample of A Hotel Management
}

\begin{abstract}
In today's competitive environment where the sale price is determined by the market, businesses need to achieve a minimum level of costs, which is the most important thing they can change in order to sustain their assets successfully and increase their profitability. With this point of view, managing customer perception of value is important in achieving the objectives of the management. In this context, instead of the inadequate traditional cost method, the target cost method is applied, which enables the management of the costs that will meet the customer demands and expectations. The aim of the study is to contribute to the accommodation managers in terms of their managerial decisions to ensure the satisfaction of business shareholders and customers by examining the relationship between customer value perception and target cost in accommodation establishments. For this purpose; A survey prepared for the customers of an accommodation company operating in Ardahan was applied and 363 customers were interviewed by using face to face interview technique. According to the results of the research; In order to reach the target cost level, the accommodation business should incorporete customer's value perception into target costing process. In this regard, in order to reach the level of profitability targeted by the enterprise, it was determined which costs would be lowered and which service parts should improve functionality.
\end{abstract}

Keywords: Customer Perception of Value, Target Cost, Target Cost Index 


\section{Giriş}

Küreselleşmenin getirdiği rekabet ortamında diğer tüm sektörlerdeki işletmeler gibi turizm endüstrisindeki konaklama işletmeleri de rakiplerine üstünlük sağlamak ve oluşan küresel pastadan pay almak için; müşteri memnuniyetini ve sadakatini sağlayarak satış kapasitesini yükseltmeyi ve maliyetlerini düşürerek karlılığı artırmayı hedeflemektedir.

Günümüzde tüketiciler ürün veya hizmeti satın alım sürecinde, uygun fiyatla kaliteli hizmet almak için piyasa araştırması yaparak satın alma kararı vermektedir. Herhangi bir konaklama işletmesine ait ürün ve hizmeti satın alan müşteri; satın alma sürecinde, tüketim aşamasında ve kullanım sonrasında algıladığı memnuniyet düzeyine ilişkin işletme web sitesi ve uygulaması üzerinden değerlendirmeler yaparak takip eden süreçte işletmenin ürün ve hizmetlerini tercih edecek müşteri potansiyelinin tercihlerini ve satın alma tutumların etkilemektedir. Müşterinin bir ürün veya hizmeti satın alırken katlanacağı maliyet ile tüketim aşamasında ve kullanımı sonrasındaki arzuladığı fayda düzeyi ilişkisi müşteri değer algısını oluşturmaktadır.

Gelişen piyasa koşulları ile birlikte işletmeler karlılıklarını artırmak için daha etkin yönetim ve maliyet planlaması yapmakta ve uygulanan bu planlar ileriye dönük işletme durumu hakkında tespitler yapma olanağ sağlamaktadır. Geçmişte uygulanan stratejik planlara ait sonuçlar işletmenin gelecekteki hedef tespitine 1şık tutması açısında önemli verileri içermektedir. Bu verilerden planlamalar ve uygulama sonuçları ile elde edilen sapmalar ve nedenleri görülebilmektedir. Gelecek dönemi kapsayan planlar ise işletme hissedarlarının bekledikleri karlılıklarına göre; hedef maliyet, hedef satış tutarı ve satış miktarının belirlenmesinde örnek teşkil edecektir.

Serbest piyasa ekonomisinde bir konaklama işletmesine ait ürün ve hizmetlere ait satış fiyatları piyasa koşullarına göre, piyasa koşulları ise pazardaki rakiplerin satış fiyatı ve değişen müşteri taleplerine göre şekillenmektedir. İşletme karlılık oranları hissedarlarının arzuladıkları kâr marjına göre belirlenmektedir. Bu sebeple konaklama işletme yönetiminin de kontrol altına alabileceği tek değişken ise maliyetlerdir. Bu nedenle geleneksel maliyet yöntemi maliyet + kâr marjına göre hesaplandığından günümüz piyasa koşullarında yetersiz kalmaktadır. 
Müşteri memnuniyetini sağlamak ve müşterilerin ürüne dair istek ve beklentilerini; kalite, fonksiyonellik, fiyat/maliyet ve zaman açısından karşılamak için daha etkin bir maliyet optimizasyonu için çağdaş maliyet yöntemlerinin kullanılması gerekmektedir.

Bu nedenle konaklama işletmeleri müşterilerine belirli aralıklarla ürün ve hizmetleri genelinde müşteri değer algısını ölçmeye yönelik anketler uygulayarak sunulacak hizmetlerin oluşturulması ve işletme hedef maliyet politikasını belirlenmesinde saptanan müşteri değer algısının hedef maliyetleme sürecinde temel alınması, işletmenin hedef pazar payının artmasına ve karlılığının yükselmesine pozitif katkılar sunacaktır.

\section{Literatür Taraması}

Tablo 1. Hedef Maliyet Yönetimi ve Müşsteri Dĕger Algısına İlişkin Literatür Taraması

\begin{tabular}{|c|c|c|}
\hline Yazar & Başlik & Özet \\
\hline Güler (2007) & $\begin{array}{l}\text { Otel İşletmelerinde Değer Ya- } \\
\text { ratma ve Müşteri Değer Algila- } \\
\text { ması Üzerine Bir Araştırma: } \\
\text { Edirne'deki Oteller Örneği }\end{array}$ & $\begin{array}{l}\text { Otel yönetiminin müşteri istek ve beklenti- } \\
\text { lerini doğru tespit ederek saptanan eksiklik- } \\
\text { lerin giderilmesi ve müşteri değeri yaratma } \\
\text { konusuna önem vermeleri gerektiği önemli } \\
\text { bir sonuç olarak saptanmıştır. }\end{array}$ \\
\hline Ural (2008) & $\begin{array}{l}\text { Değer Temelli Fiyatlama: Ürünün } \\
\text { Tüketici Değer Algısına Göre Fi- } \\
\text { yatlanması }\end{array}$ & $\begin{array}{l}\text { Çalışmada tüketicinin değer algısını belirle- } \\
\text { yen başlıca etkenler ve değer temelli fiyat- } \\
\text { lama yöntemi hipotetik örnek bir uygulama } \\
\text { yöntemi ile açıklanmaktadır. }\end{array}$ \\
\hline $\begin{array}{l}\text { Okutmuş ve } \\
\text { Ergül (2015) }\end{array}$ & $\begin{array}{l}\text { Konaklama İşletmelerinde Hedef } \\
\text { Maliyetleme, Değer Analizi ve Ka- } \\
\text { izen Maliyetleme Yöntemlerinin } \\
\text { Birlikte Uygulanabilirliğine İlişkin } \\
\text { Bir Araştırma }\end{array}$ & $\begin{array}{l}\text { Müşteri istek ve beklentilerine uygun ürün } \\
\text { ve hizmet sunabilmek ve ortakların arzula- } \\
\text { dığı kara ulaşabilmek için işletmenin hangi } \\
\text { parçalarda ne oranda maliyet azaltacağını } \\
\text { ve hangi parçalarda özelliklerin geliştirile- } \\
\text { ceği belirlenmiştir. }\end{array}$ \\
\hline Çolak (2018) & $\begin{array}{l}\text { Her Şey Dâhil Sistemde Fiyat Du- } \\
\text { yarlllı Ölçümü ve Kalite Maliyet- } \\
\text { leri Yönetiminin Hedef Maliyet- } \\
\text { leme Sürecine Entegrasyonu: Bir } \\
\text { Otel İşletmesinde Uygulama }\end{array}$ & $\begin{array}{l}\text { Konaklama işletmeleri mevcut oda satış ge- } \\
\text { lirlerinin üzerinde oda satışı gelirlerine sa- } \\
\text { hip olabileceği, başarısızlı maliyetlerini } \\
\text { elimine ederek arzuladığı kâr ve maliyet he- } \\
\text { define ulaşabileceği ve ek yatırım gerektir- } \\
\text { meden sunduğu kalite seviyesini iyileştire- } \\
\text { bileceği tespit edilmiştir. }\end{array}$ \\
\hline $\begin{array}{l}\text { Yildız ve Çiğ- } \\
\text { dem (2018) }\end{array}$ & $\begin{array}{l}\text { Havayolu Hizmet Kalitesinin } \\
\text { Müşteri Memnuniyeti Üzerindeki } \\
\text { Etkisinin Yapisal Eşitlik Modeli ile } \\
\text { Analizi }\end{array}$ & $\begin{array}{l}\text { Havayolu hizmet kalitesinin müşteri mem- } \\
\text { nuniyetini, marka imajını ve algılanan de- } \\
\text { ğeri pozitif yönde anlamlı olarak etkilediği } \\
\text { bulgusuna ulaşılmıştır. Algılanan değer ve } \\
\text { marka imajının da müşteri memnuniyetini } \\
\text { pozitif yönde anlamlı olarak etkilediği tes- } \\
\text { pit edilmiştir. }\end{array}$ \\
\hline
\end{tabular}




\section{Müşteri Değer Algısı}

Oliver'a göre müşteri değer algısı; "ürünün kullanımı veya tecrübe edilmesi sonucu elde edilenler ile ürünü elde etme maliyetlerinin karşılaştırılması sonucu ortaya çıkan yargı olarak tanımlamaktadır" (Oliver, 2015).

Müşteri değer algisı genellikle, müşterinin aldığı ürün veya hizmet karşılığında vazgeçtikleri arasındaki bir değişimin sonucudur. Değer, müşterinin satın almış olduğu hizmet karşılığında katlandığı maliyetler ile kendisine sunulan hizmetten elde etmiş olduğu fayda arasındaki ilişkinin kıyaslanmasıdır. Fiyat genellikle almak istenilen ürün ve hizmet karşılığında neyi feda etmek istediğini göstermek için kullanılır. Ancak zaman ve fiziksel çabalar gibi parasal olmayan maliyetlerin de hizmeti elde etmenin getirdiği harcamalar olarak kabul edilmektedir (Yıldız ve Çĭğdem, 2018, s.239).

Çetintürk (2016) müşteri değeri kavramına ait özellikleri şu şekilde belirtmiştir:

- Müşteri değeri, müşterinin algıladığı toplam değerdir.

- Müşteri değeri, satın alınan ürünün müşteriye sağladığı toplam fayda ile toplam maliyetlerin müşteri tarafından oransal olarak kıyaslanmasıdır.

- Müşteri değerinin artırılmasında; müşteriye sunulan faydaların artırılması kadar müşterinin katlanacağı maliyetlerin de minimum seviyeye indirilmesi önemlidir.

- Müşterilerin değer algısı kişiye göre farklılık gösterebileceğinden özneldir.

- Müşteri değerinin oluşmasında ürün ve hizmete ait özelliklere ek olarak ürün ve hizmetin sunum şekli ve müşteri ilişkileri önemli etkendir.

Müşteri için değer yaratma, satın alma sürecinde müşteri beklentileri ve ürünü satın alıp kullanımı sonrası ürün deneyimiyle ilgili bir yaklaşımdır. Müşteri için değer yaratma, müşterinin katlandığ1 maliyetler karşılığında beklediği değerden fazlasını elde etme durumudur. Başka bir ifadeyle değer yaratma; müşterinin katlanacağı maliyetler sabit kalarak müşteriye daha fazla fayda sunmaktır. Bu yaklaşıma göre eğer yaratılan 
değer, müşteriye yönelik değil ise, anlamlı değildir (Cop ve Yüzüak, 2016, s.54).

\section{Müsşteri Değer Algısını Etkileyen Faktörler}

Algılanan değer, müşterinin ürüne ait elde etmiş olduğu faydaların toplam olarak değerlendirmesidir. Müşteri tarafından ürüne ait değer algılama; fiyat, kalite, fayda, harcama kavramlarının hepsini içine almaktadır (Akın ve Seçgin, 2014, s.30).

Müşteri değer alg1sı, işletmenin tüketiciye sunduğu ürünün; ürün özellikleri, ürünün elde edilme süreci, ürün deneyimi ve maliyetler olmak üzere dört temel özelliği kapsamaktadır. Müşteriye sunulan ürünün alg1 değerini etkileyen başlıca faktörler; ürün özellikleri, ürünün elde edilme süreci, ürün deneyimi ve ürün elde etme maliyetlerdir (Ural, 2008, s.5).

\section{Ürün}

Ürün özellikleri boyutu; ürüne ait performans, fonksiyonel özellikler ve sahip olduğu teknolojik yenilik bazında tüketici tarafından değerlendirilmesidir. İşletmeler sahip olduğu ürün ve hizmetleri iyileştirmek adına genellikle; $A \& G$, ürün tasarımı, mühendislik alanlarına önem vermektedir. Ancak, bu alanlarda çalışan personel müşteri beklentilerini karşılamaya odaklanmakta ve müşterilerin değerli bulduğu nitelikleri değil, ürüne teknik olarak üstün özellikleri eklemeyi planlamaktadır. Çoğu zaman bu üstün özellikler müşterilerce kullanılmadığı gibi gerekli de görülmemektedir (Ural, 2008, s.5).

\section{Ürünü Elde Etme Süreci}

Ürünün elde etme süreci; müşteri talep ettiği ürüne ulaşılabilirliği, tedarikçi güvenirliliği ve dağıtım kanalı nezdinde değerlendirilir. Müşteri satın almak istediği ürünü istediği yerde ve zamanda almayı arzuladığında, bu koşulu yerine getiren işletmeyi diğerlerine tercih etmektedir. İşletme ürün arzında sürekliliği sağlamak amacıyla stoklamayı en uygun miktarda yapmalıdır. Tedarikçinin müşterisine ürün teslimi hususunda rakiplerine 
göre daha hızlı ve güvenilir olması müşterinin sunulan hizmete karşı algıladığı değeri olumlu yönde etkileyecektir. Söz konusu bu özellikler işletmeye rakiplerine kıyasla daha yüksek fiyatla ürün ve hizmet pazarlayabilmesine olanak sağlar (Ural, 2008, s.5).

\section{Ürünü Deneyimi}

Müşterinin ürüne ait deneyimi; ürünün markası, satış elemanının müşteri ile iletişimi, problemi giderme ve işletmenin satış sonrası hizmetlerinin değerlendirilmesinde oluşmaktadır. Müşterinin istek ve ihtiyaçlarına göre problemlerin çözüme ulaşması ve satış sonrası hizmetlerin de ürün paketinin içine eklenmesi; işletmeye ürününü standart ürünlerden pozitif yönde ayrışmasına katkı sağlar. Müşteri deneyiminin olumlu çıkması için gerekli önlemleri alan işletmeler, müşteri sadakatini ve bağlılığını sağlayabilirler (Ural, 2008, s.5).

\section{Maliyetler}

Maliyetler uzlaşmaya varılacak en zor alanlardan bir tanesidir. Hem işletme hem de müşteri sadece ürünün satış fiyatına odaklanırlar. Esasen müşteri, ürünün satıcıya kaça maliyetiyle ilgilenmez. Müşteriyi ilgilendiren husus ürünü satın alma maliyetidir. Bu maliyetler (Ural, 2008, s.6);

- Ürünü satın alma sürecinde doğru ürün ve doğru satıcıyı ulaşma maliyetleri

- Satış sözleşmelerinde yer alan yönetsel ve yasal maliyetler

- Ürünün kullanım sonrası orya çıkan atık maliyetleri

- Müş̧terinin ürünü nasıl kullanacağının öğrenmesine dayalı kişisel maliyetler

- Satın alınan ürün ile diğer ürünler arasındaki performans farkl1lıklarının maliyetleri

İşletme ürün ve hizmetlerini müşterilere sunarken belirtilen maliyetlerin her birinin müşteriye olan maliyetini dikkate almalıdır. 


\section{Hedef Maliyetleme}

Bilgi teknolojileri alanında yaşanan gelişmeler, müşteri taleplerindeki değişimler ve küreselleşme ile rekabet ortamının daha geniş alana taşınması; oluşan küresel piyasa koşulları işletmeleri faaliyetlerini sürdürebilmeleri ve karlılığını sağlayabilmesi için kısa zamanda minimum maliyetle yüksek kalitede mal ve hizmet üretmeyi hedeflemesi gerekmektedir. İşletmeler koymuş oldukları hedeflere uluşmak için geleneksel maliyet yönteminin yerine modern tekniklerden en önemlilerinden biri olan hedef maliyetleme yöntemini kullanmaya başlamışlardır (Çakır, 2018, s.3; Karahan, 2018, s.367).

Japon şirketleri tarafından 1970'li yıllarda meydana gelen petrol krizi nedeniyle firmalar üretim ve satış faaliyetlerini kontrol etmek amacıyla geliştirdikleri hedef maliyetleme; ürünün yaşam seyri boyunca bir taraftan üretim maliyetlerinin düşürülmesini hedeflerken diğer yandan kar artışını amaçlayan maliyet yönetim sürecidir (Kaya, 2010, s.315).

Hedef maliyetleme, maliyet ve kar planlamasında geleneksel maliyet yönteminden (maliyet + kar marjı) farklı olarak sistem tersine işler; fiyat, kar, ve maliyete dair temel faktörlerin pazara yönelik olarak birleşimini öne sürmektedir (Alagöz, Yılmaz ve Ay, 2005, s.8; Terzi, 2017, s.223).

$\mathrm{Bu}$ nedenle hedef maliyetler hesaplanma sürecinde, ilk olarak pazar payı için gerekli olan hedef satış fiyatı ve arzulanan hedeflenen kar oranı hesaplanır. Hedef satış fiyatı; bir ürüne ait müşterilerin algı düzeylerine göre verdikleri değere dayalı olarak oluşan satış fiyatıdır. Hedef satış fiyatı belirlenmesinde rakip ürünlerin satış fiyatları ile hedef kitlenin ödeme arzusu ve gücü dikkate alınır. Hedef kâr marjı; uzun dönemli kâr analizine dayalı olarak oluşturulan kâr marjıdır. Yatırılan sermayenin geri dönmesi arzulanan yüzdesi, yatırımın karlılığa oranıdır. Hedef kâr marjı, bu oran çerçevesinde belirlenir. Burada, satış fiyatı ile kâr marjı arasındaki fark hedef maliyeti vermektedir (Aksoylu ve Dursun, 2001,s.362).

Kısaca hedef maliyetleme; piyasa koşullarında bir ürün veya hizmet için belirlenen satış fiyatından işletme yönetiminin hedeflediği kar marjı çıkarılarak işletmenin uluşması gereken maliyeti ifade etmektedir (Acar ve Şenol, 2014, s.3).

Hedef maliyetlemenin özellikleri aşağıdaki gibi sıralanabilir (Alagöz, Yilmaz ve Ay, 2005, s.48): 
- Hedef maliyetleme ürünün planlanması ve tasarımı aşamasında kullanilır.

- Hedef maliyetleme müşteri odaklı bir yöntemdir olup hedeflenen maliyet pazar tarafından belirlenmektedir.

- Hedef maliyetleme, stratejik bir maliyet yönetim sistemidir.

- Hedef maliyetleme, ürünün yaşam seyri boyunca uygulanan bir maliyet yönetimidir.

- Hedef maliyetleme, maliyet planlamasıdır, maliyet kontrol yöntemi değildir.

- Hedef maliyetleme, maliyetlerin oluşmasından önce yönetimi ilkesine dayanir.

- Hedef maliyetleme, mühendisleri, ilgilileri ve çalışanları ürün, teknoloji ve tasarımın maliyet etkilerini araştırmaya yönelik olarak etkileyen bir yöntemdir.

- Hedef maliyetleme, işletme bölümlerini bir bütün olarak ele alan bir grup yönetimidir.

\section{Hedef Maliyetlemenin Temel İlkeleri}

Hedef maliyetleme sürecinin kavramsal çerçevesi altı temel ilkeden oluşmaktadır. Bu altı ilke; fiyata göre maliyetleme, müşteriler üzerinde yoğunlaşma, tasarım üzerinde yoğunlaşma, geniş kapsamlı katılım, yaşam seyri yaklaşımı ve değerler zinciriyle ilgilenme şeklinde sıralanabilir (Alpkan, 2012, s.55).

\section{Fiyata Göre Maliyetleme}

Ürün veya hizmete ait fiyat piyasa koşulları tarafından belirlenmekte, hedef kar marjı ise işletme ortakları ve işletme stratejilerine göre saptanması nedeniyle işletme yönetiminin kontrol edebileceği tek şeyin değişken maliyetler olması prensibine dayanmaktadır (Kutay ve Akkaya, 2000, s.2; Okutmuş ve Ergül, 2015, s.99). 


\section{Müş̧teriler Üzerinde Yoğunlaşma}

İşletme tarafından üretilen ya da üretilmesi planlanan ürün ve hizmetler müşteri talepleri dikkate alınarak; kalite, fonksiyon, zaman ve fiyata göre karşılanması ve bu unsurların maliyet düşürme kapsamında sürekli dikkate alınması gerekmektedir. İşletme hedef pazar payına ulaşmak için müşteri odaklı pazarlama faaliyetleri yürütmekte ve müşteri işletme için en önemli odak noktasını oluşturmaktadır. Bu nedenle müşterinin firmadan ne istediği ve firmanın müşteri beklentilerini karşılamak için neler yapması gerektiğinin kavranması yöneticiler açısından önem arz etmektedir (Geçgin, 2013, s.36).

\section{Tasarm Üzerinde Yoğunlaşma}

Hedef maliyetleme, ürün tasarımını maliyet yönetimi için anahtar olarak kabul etmektedir. Ürün ve hizmet üretim maliyetlerinin yaklaşık \%80-85 oranındaki kısmı tasarım aşamasında belirlendiğinden, tasarım aşaması hedef maliyetleme yönteminin odak noktasıdır. Tasarım üzerine yoğunlaşmada, maliyet artışı ve zaman alıcı değişiklikleri yok etmek amaçlanmaktadır. Ürün ve hizmetin tasarım aşamasında dikkat edilmesi gereken unsurlardan birisi de tüketiciler tarafından değeri olmayan, ürünün fiyatını artırmadığı halde maliyetini artıran özelliklerini ortadan kaldırılmasıdır (Haşaşoğlu, 2011, s.59).

\section{Geniş Kapsamlı Katılım}

Müşteri ihtiyaçlarının belirlenmesi ile başlayan müşteri taleplerine uygun özellikte ve istenilen kalitede ürün ve hizmet üretme faaliyetlerini kapsayan hedef maliyetleme sürecinin başarıyla gerçekleşmesi için farklı uzmanlık alanlarına sahip olan kişilerin de sürece dahil edilmesi gerekmektedir (Çolak, 2018, s.129). Tasarım sırasında tüm ekibin sürece dahil edilmesi, daha sonra ortaya çıkabilecek problemlerin önceden saptanmasina yardımci olur (Ansari, Bell, ve Okano, 2007, s.513).

Bu nedenle bir ürünün hedeflenen maliyet veya altında üretilebilmesi için pazar araştırması, tasarım mühendisliği, satış, üretim mühendisliği, satın alma, üretim, pazarlama, maliyet yönetimi gibi işletme içi birçok 
farklı fonksiyona sahip kişilerin hedef maliyetleme sürecine katılımı gerekmektedir. Ayrıca hedef maliyetleme sürecine; satıcılar, aracılar, dağıtıcılar, müşteriler gibi işletme dışı kişi veya gruplar da dâhil edilmesi gerekmektedir. Grubu oluşturan her bir birim ortak amaçları olan hedef maliyete ulaşmak için kendi üzerine düşen sorumlulukları en iyi şekilde yerine getirmek zorundadır. Grubun başarısı, gurubu oluşturan kişilerin projeyi iyi anlamalarına, projenin gerekliliğine inanmalarına ve sorumluluk almalarına bağlıdır (Ceran ve Özdemir, 2013, s.460; Çolak, 2018, s.129130).

\section{Yaşam Seyri Yaklaşımı}

Bir ürüne ait yaşam seyri maliyetleri; araştırma-geliştirme faaliyetleri, üretim, dağıtım, servis, garanti ve imha işlemlerinde gerçekleştirilen toplam ürün maliyetlerinden oluşmaktadır. (Andersen, 1998, s.22). Hedef maliyetleme yöntemi; ürünün yaşam seyrince gerek tüketici için gerekse üretici için yaşam döngüsü maliyetlerini minimize ederek uzun dönemde karlılı̆̆ maksimize etmeyi amaçlamaktadır (Akkaya, 2010, s.10-11).

\section{Değer Zinciriyle İlgilenme}

Hedef maliyet yönteminde hedeflenen maliyete ulaşılması için hedef maliyetleme sürecini oluşturan; tedarikçilerden dağıtıcılara ve müşteriye hizmet sunanlara kadar değer zincirinin tüm üyelerinin işbirliği içinde çalışmaları gerekmektedir (Çolak, 2018, s.130; Okutmuş ve Ergül, 2015, s. 99).

Müşteri için değer ifade eden; özellik, zaman ve kalite ile harekete geçen maliyetleme yöntemi, müşteri isteklerinin karşılanma düzeyleri ve müşterilerin ürün ve hizmete dair ödemeye hazır olduğu tutarı saptanarak analize başlamaktadır. (Öğünç, 2010, s.17).

\section{Araştırmanın Amacı ve Önemi}

$\mathrm{Bu}$ çalışmada; konaklama işletmelerinde müşteri değer algısı ve hedef maliyet arasındaki ilişki düzeyleri incelenerek, işletme hissedarları ve 
müşterilerinin memnuniyetini sağlamak için konaklama işletmesi yöneticilerine alacakları yönetsel kararlarda katkı sağlaması amaçlanmıştır. Bu kapsamda; Ardahan ilinde faaliyet gösteren bir otel işletmesinde uygulama gerçekleştirilmiştir.

Günümüzde konaklama işletmelerinde geleneksel maliyet hesaplama yöntemlerinin yerine hedef maliyetleme yöntemi uygulanmaktadır. Bu nedenle, hedef maliyetleme sürecinde müşteri memnuniyetini artırmak ve devamlılı̆̆ı sağlamak için müşteri değer algısının dikkate alınması gereken bir ölçüt olduğunun önemini ortaya koymaktadır.

\section{Araştırmanın Yöntemi}

$\mathrm{Bu}$ bölümde, araştırmanın amacı, formunun hazırlanması, araştırmanın yöntemi ve kapsamı konularına yer verildikten sonra, tanımlayıcı istatistikler çerçevesinde değerlendirmeler yapılmaktadır. Yapılan analizlerden elde edilen bulgulara göre değerlendirmeler yapılmıştır.

\section{Araştırmanın Yöntemi ve Kapsamı}

Çalışmada nicel araştırma tekniklerinden olan anket yöntemi yüz yüze görüşme şeklinde uygulanmıştır. Araştırma kapsamında Ardahan ilinde faaliyet gösteren bir otel işletmesinin 2018 yılı kasım ve aralık aylarında konaklayan müşterilerin değer algılarını ölçmeye yönelik anket soruları hazırlanmıştır.

Müşterilerin değer algısını ölçmeye yönelik Okumuş ve Ergül 2015; Okan, 2018 çalışmalarında kullandığ anket formları uygulanmıştır. 5'li likert tipi olarak düzenlenmiş olan üç bölüme ait altışar olmak üzere toplamda 18 ifade bulunmaktadır. Bu sorular; "Çok Önemli" seçeneği için 5, "Önemli" seçeneği için 4, "Biraz Önemli" seçeneği için 3, "Önemsiz" seçeneği için 2, "Çok Önemsiz" seçeneği için 1 puan şeklinde derecelendirilmiştir.

Ayrıca durum çalışması yapılan otel işletmesine ait belirli dönemleri kapsayan; oda satış verileri ve bölüm bazında maliyet bilgilerinden yararlanilacaktır. 


\section{Araştırmanın Evren ve Örneklemi}

Kış turizm potansiyelinin bulunduğu Ardahan ilinde 2018 yılı kasım ve aralık ayında konaklayan müşteriler üzerinde anket yapılmıştır. Belirtilen tarih aralığında otel kayıtlarına göre bir konaklama yapan 2.400 müşteri sayısı ana kütle olarak alınmıştır.

Farklı büyüklükteki evrenler için kuramsal örneklem büyüklükleri için 5.000 kişilik evrende \%5 hata oranı ile gerekli örneklem sayısı 356'dır (Balc1, 2011, s.106). Bu bağlamda otel işletmesinde konaklayan 365 müşteriye anket uygulanmıştır fakat yapılan anketlerden iki tanesi geçersiz olduğundan 363 kişinin anketi değerlendirilmiştir.

\section{Bulgular ve Tartışma}

Uygulama yapılan konaklama işletmesinden elde edilen bilgileri ve müşterilerin değer algısını ölçmeye yönelik yapılan anketten elde edilen bulgular değerlendirilmiştir.

\section{Konaklama İşletmesinden Elde Edilen Bilgiler}

Konaklama işletmesinden elde edilen bilgiler işletme yönetiminin isteği üzerine gizli tutulmuştur. İşletmeden elde edilen mali ve sayısal bilgiler tablo 2'de özet olarak gösterilmektedir.

Tablo 2. Konaklama İşletmesine Ait Mali ve Sayısal Bilgiler

\begin{tabular}{|c|c|c|c|c|c|}
\hline \multicolumn{6}{|c|}{2018 Yılı Kasım ve Aralık Dönemini Bilgileri } \\
\hline \multicolumn{2}{|c|}{ Kişi Başı Fiili Satış Fiyatı } & $50,00 \mathrm{TL}$ & \multicolumn{2}{|c|}{ Satış Gelirleri } & $120.000,00 \mathrm{TL}$ \\
\hline \multicolumn{2}{|c|}{ Kişi Başı Fiili Maliyet } & $27,50 \mathrm{TL}$ & \multicolumn{2}{|c|}{ Satılan Hizmetin Maliyeti } & $66.000,00 \mathrm{TL}$ \\
\hline \multicolumn{2}{|c|}{ Oluşan Kar Marjı } & $\% 45$ & \multicolumn{2}{|c|}{ Kat Hizmetleri Toplam Maliyeti } & $28.000,00 \mathrm{TL}$ \\
\hline \multicolumn{2}{|c|}{ Satılan Yatak } & 2.400 & \multicolumn{2}{|c|}{ Ön Büro-Odalar Toplam Maliyet } & $25.000,00 \mathrm{TL}$ \\
\hline \multicolumn{2}{|c|}{ Müşteri Sayısı } & 1.600 & \multicolumn{2}{|c|}{ Yiyecek-İçecek Toplam Maliyet } & $13.000,00 \mathrm{TL}$ \\
\hline \multirow{2}{*}{$\begin{array}{l}2018 \\
\text { Y1li }\end{array}$} & $\begin{array}{l}\text { Satışa Hazır } \\
\text { Yatak Sayısı }\end{array}$ & 22.000 & \multirow{2}{*}{$\begin{array}{l}2019 \\
\text { Yilı }\end{array}$} & $\begin{array}{l}\text { Kişi Başı } \\
\text { Hedef Satış Fiyatı }\end{array}$ & $60,00 \mathrm{TL}$ \\
\hline & $\begin{array}{l}\text { Satılan } \\
\text { Yatak Sayıs1 }\end{array}$ & 16.000 & & Hedef Kar Marj1 & $\% 50$ \\
\hline
\end{tabular}


Konaklama İşletmesine Ait Kişi Başı Fiili Satış Fiyatı, Kişi Başı Fiili Maliyet, Kişi Başı Kar, Hedef Kar ve Hedef Maliyetin Hesaplanması

Kişi başı fiili satış fiyatı; Tablo 1'deki verilere dayanarak işletmenin belirtilen dönemdeki fiili satış gelirlerinin yine belirtilen bu dönemdeki yatak sayısına bölünmesi sonucu hesaplanır.

Kişi Başı Fiili Satış Fiyatı $=$ Satış Gelirleri/Satılan Yatak Sayısı $=120.000,00 /$ $2.400=50,00 \mathrm{TL}$

Kişi başı fiili satış maliyet; Tablo 1'deki verilere dayanarak işletmenin belirtilen dönemdeki satılan hizmet maliyetinin yine belirtilen bu dönemdeki yatak sayısına bölünmesi sonucu hesaplanır.

Kişi Başı Fiili Maliyet $=$ Satılan Hizmetin Maliyeti/Satılan Yatak Sayısı = $66.000,00 / 2.400=27,50 \mathrm{TL}$

Yapılan hesaplamalarda konaklama işletmesinin 2018 yılı kasım ve aralık ayı kişi başı fiili satış fiyatı 50,00 TL olup, yine aynı dönemdeki kişi başı fiili maliyeti ise 27,50 TL'dir. Belirtilen dönemde uygulama işletmesinin kişi başı karı; kişi başı fiili satış fiyatından yine aynı dönemdeki kişi başı fiili maliyetin çıkarılması sonucu hesaplanır.

Kişi Başı Fiili Kar $=$ Kişi Başı Fiili Satış Fiyatı - Kişi Başı Maliyet $=50,00-$ $27,50=22,50 \mathrm{TL}$

Konaklama işletmesinden elde edilen bilgilere göre 2019 yılı hedef satış fiyatı olarak 60,00TL ve hedef kar marjı olarak ise \%50 olarak belirtilmiştir.

Hedef Kar $=$ Hedef Satış Fiyatı \% Kar Marjı =60,00 TL \% 50= 30,00 TL

İşletmenin 2019 yılı hedef maliyeti, işletmenin hedeflediği satış fiyatından hedef karın çıkarılması sonucu hesaplanır.

Hedef Maliyet $=$ Hedef Satış Fiyatı - Hedef Kar $=60,00-30,00=30,00 \mathrm{TL}$

\section{Hizmet Fonksiyonlarına Ait Müşteri Değer Algısının Belirlenmesi}

Araştırma kapsamında 363 otel müşterisinin değer algısını ölçmeye yönelik olarak uygulanan anket bulgularına göre hizmet bölümlerinin fonksiyonlarına ait müşteri önem dereceleri tablo $3^{\prime}$ te verilmiştir. 
Müşterilerin konaklama işletmesinin sunduğu hizmetler sonucu algılamış oldukları bölüm bazındaki alt fonksiyonlarının saptanabilmesi için müşterilere yöneltilen değer algısını ölçmeye yönelik sorulara; "Çok Önemli" seçeneği için 5, "Önemli" seçeneği için 4, "Biraz Önemli" seçeneği için 3, "Önemsiz" seçeneği için 2, "Çok Önemsiz" seçeneği için 1 puan şeklinde cevap vermesi istenmiştir. Müşterilerin anket sorularına vermiş olduğu cevapların değerlendirmesi sonucu konaklama işletmesi alt hizmetlerine ait müşteri önem derecelerine ait ortama, genel puan ve yüzdesel ağırlıkları tablo3'de olduğu gibi belirlenmiştir.

\section{Hesaplanma Yöntemi Örneği}

Hizmeti oluşturan her alt fonsiyonlar kendi arasında bölüm bazında ortalamarın geçerli olan 363 anket sayı ile çarpılması sonucu müşteri önem derecesi puanı hesaplanmaktadır.

Tablo 3. Hizmet Bölümlerinin Fonksiyonlarına Ait Müşteri Önem Dereceleri

\begin{tabular}{|c|c|c|c|c|}
\hline \multirow{2}{*}{$\begin{array}{l}\text { Hizmet } \\
\text { Bölümleri }\end{array}$} & \multirow{2}{*}{ Alt Fonksiyonları } & \multicolumn{3}{|c|}{ Müşteri Önem Dereceleri } \\
\hline & & Ortalama & Puan & $\%$ \\
\hline \multirow{6}{*}{$\begin{array}{l}\text { Ön Büro } \\
\text { Danışmanlık } \\
\text { Hizmetleri }\end{array}$} & Karşılama/Yerleştirme & 4,66 & 1692 & 17,33 \\
\hline & Bilgilendirme & 4,50 & 1634 & 16,73 \\
\hline & Teknik Destek & 4,58 & 1663 & 17,03 \\
\hline & Şikâyet ve Taleplerin Çözülmesi & 4,47 & 1624 & 16,63 \\
\hline & Döviz Bozdurma İşlemleri & 4,45 & 1617 & 16,56 \\
\hline & Çıkış ve Ödeme İşlemleri & 4,23 & 1536 & 15,73 \\
\hline \multirow{6}{*}{$\begin{array}{l}\text { Kat } \\
\text { Hizmetleri- } \\
\text { Konaklama } \\
\text { (Oda) }\end{array}$} & Oda Temizliği & 4,76 & 1729 & 17,86 \\
\hline & Oda Havlu, Çarşaf vb. Değişimi & 4,50 & 1633 & 16,87 \\
\hline & Minibar & 4,41 & 1600 & 16,53 \\
\hline & Buklet Malzemeleri & 4,38 & 1590 & 16,42 \\
\hline & Oda Donanımlarının Aktif Olması & 4,48 & 1626 & 16,80 \\
\hline & Genel Alanların Temizliği & 4,14 & 1503 & 15,53 \\
\hline \multirow{6}{*}{$\begin{array}{l}\text { Yiyecek- } \\
\text { İçecek }\end{array}$} & 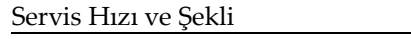 & 4,74 & 1721 & 17,78 \\
\hline & Çeşitlilik & 4,41 & 1601 & 16,54 \\
\hline & Lezzet ve Kalite & 4,37 & 1587 & 16,39 \\
\hline & Doyuruculuk/Porsiyon & 4,39 & 1594 & 16,47 \\
\hline & Hijyen ve Temizlik & 4,44 & 1612 & 16,65 \\
\hline & Sunum/Görsellik & 4,31 & 1565 & 16,17 \\
\hline
\end{tabular}

Her bir hizmet bölümünü oluşturan altı alt fonksiyon bölüm bazındaki müşteri önem görecesi bölümü oluşturan alt hizmet puanlarının toplamının ilgili alt fonksiyona bölünmesiyle hizmet bölümü içerisindeki 
müşteri önem derecesi yüzdesel değeri hesaplanır.

Tablo $3^{\prime}$ te hizmet bölümlerinin fonksiyonlarına ait önem dereceleri incelendiğinde; ön büro hizmetlerinin alt fonsiyonu olarak karşılama ve yerleştirmenin müşteriler nezlinde diğer alt hizmetlere oranda daha büyük öneme sahip olduğu görülmektedir. Kat hizmetler ve konaklama hizmetleri içerisinde yer alan oda temizlği diğer alt fonsiyonlara göre daha fazla müşteri önem görecesine sahiptir. Yiyecek içecek hizmetleri içerisinde ise servis hızı ve şekli diğer alt fonsiyonlarla karşılaştırıldığında önem görecesini yüksek olduğu görülmektedir.

\section{Her Bir Parçanın Maliyetinin Saptanması}

Uygulama yapılan işletmeye ait mali bilgilerinden faydalanılarak hizmet parçalarının maliyetleri belirlenmiştir. Hizmet parçalarını maliyetleri ve hizmeti oluşturan alt parçaların maliyetleri ve bölüm içerisindeki maliyet payları hesaplanarak tablo 4 'te verilmiştir.

\section{Maliyet Payı Hesaplama Yöntemi Örneği:}

Ön büro hizmetleri parçasının alt parçası olan personel parçasının maliyet payı 17.500,00TL $/ 25.000,00 \mathrm{TL}=0,70$ olarak hesaplanmıştır.

Tablo 4. Hizmet Parçalarının Maliyetleri ve Maliyet Paylan

\begin{tabular}{|c|c|c|c|}
\hline \multirow{5}{*}{$\begin{array}{l}\text { Önbüro } \\
\text { Danışmanlık } \\
\text { Hizmetleri }\end{array}$} & Parçaları & Maliyeti & Maliyet \% \\
\hline & Personel & $17.500,00 \mathrm{TL}$ & $\% 70$ \\
\hline & Sarf Malz. & $6.000,00 \mathrm{TL}$ & $\% 24$ \\
\hline & Basılı Evrak & $1.500,00 \mathrm{TL}$ & $\% 6$ \\
\hline & Toplam & $25.000,00 \mathrm{TL}$ & $\% 100$ \\
\hline \multirow{6}{*}{$\begin{array}{l}\text { Kat } \\
\text { Hizmetleri } \\
\text { Konaklama } \\
\text { (Oda) }\end{array}$} & Parçaları & Maliyeti & Maliyet \% \\
\hline & Personel & $15.000,00 \mathrm{TL}$ & $\% 53,58$ \\
\hline & Sarf Malz. & $9.000,00 \mathrm{TL}$ & $\% 32,14$ \\
\hline & Temizlik & $3.000,00 \mathrm{TL}$ & $\% 10,71$ \\
\hline & Buket Malz. & $1.000,00 \mathrm{TL}$ & $\% 3,57$ \\
\hline & Toplam & $28.000,00 \mathrm{TL}$ & $\% 100$ \\
\hline \multirow{5}{*}{ Yiyecek İçecek } & Parçaları & Maliyeti & Maliyet \% \\
\hline & Personel & $8.000,00 \mathrm{TL}$ & $\%$ 61,54 \\
\hline & Pişirme & $1.000,00 \mathrm{TL}$ & $\% 7,69$ \\
\hline & Hazırlık (Alınan Malzeme) & $4.000,00 \mathrm{TL}$ & $\% 30,77$ \\
\hline & Toplam & $13.000,00 \mathrm{TL}$ & $\% 100$ \\
\hline
\end{tabular}




\section{Hizmeti Oluşturan Parçaların Görece Öneminin Belirlenmesi}

Hizmeti oluşturan parçaların göre ağırlıklarının belirlenmesinde; hizmet fonksiyonlarının müşteri değer algı dereceleri ile hizmeti oluşturan parçalar bir matriste karşılaştırılmıştır.

Hizmeti oluşturan her bir alt parçanın işletmeden elde edilen verilere göre harcama içindeki payları hesaplanması sonucu işletme harcamalrı içerisinde en çok paya sahip olan kalem personel giderleridir.

Ön büro-danışmanlık hizmeti alt parçası olan personelin hizmeti oluşturan tüm parçalar içerisindeki görece önem derecesinin yüzdesel olarak saptanması: personel parçasına ait alt fonksiyonların müşteri değer alg1 derecelerinin toplamının ön büro- danışmanlık hizmetini oluşturan tüm parçaların müşteri değer algısı derecelerinin toplamına bölünmesi ile hesaplanmaktadır.

\section{Parçalarn Görece Önem Derecesi Hesaplama Yöntemi Örneği:}

Personel Alt Parçası Önem Görecesi= Personel Alt Parçasının Toplam MDA/ Hizmetin Toplam MDA $=505 / 600=0.842$

İfade edilen bu hesaplama yöntemi diğer tüm alt parçalarda uygulanarak parçaların görece önem dereceleri belirlenmiştir.

Tablo 5. Ön büro- Danışmanlık Hizmetleri Alt Parçalarının Fonksiyonlarına Görece Önem Dereceleri

\begin{tabular}{|c|c|c|c|c|c|c|c|}
\hline \multirow{4}{*}{$\begin{array}{l}\text { Ön Büro- } \\
\text { Danışmanlık } \\
\text { Hizmetleri } \\
\text { Alt Parçaları }\end{array}$} & \multicolumn{6}{|c|}{$\begin{array}{c}\text { Ön Büro-Danışmanlık Hizmetleri Alt Fonksiyonlarının } \\
\text { Müşteri Görece Önem Dereceleri }\end{array}$} & \multirow{4}{*}{$\begin{array}{r}\text { Par- } \\
\text { çaların } \\
\text { Görece } \\
\text { Önemi } \\
\%\end{array}$} \\
\hline & $\begin{array}{c}\text { Karşılama- } \\
\text { Yer- } \\
\text { leştirme }\end{array}$ & $\begin{array}{l}\text { Bilg- } \\
\text { ilen- } \\
\text { dirme. }\end{array}$ & $\begin{array}{l}\text { Teknik } \\
\text { Destek }\end{array}$ & $\begin{array}{c}\text { Şikâyet ve } \\
\text { Taleplerin } \\
\text { Karşılanması }\end{array}$ & $\begin{array}{c}\text { Döviz } \\
\text { Bozdurma } \\
\text { İşlemleri }\end{array}$ & $\begin{array}{l}\text { Çıkış } \\
\text { ve } \\
\text { Ödeme } \\
\text { İşlem- } \\
\text { leri }\end{array}$ & \\
\hline & $\%$ & $\%$ & $\%$ & $\%$ & $\%$ & $\%$ & \\
\hline & 17,33 & 16,73 & 17,03 & 16,63 & 16,56 & 15,73 & \\
\hline Personel & 90 & 85 & 70 & 85 & 90 & 85 & 0,842 \\
\hline $\begin{array}{l}\text { Sarf } \\
\text { Malzemeleri }\end{array}$ & 5 & 10 & 5 & 5 & 5 & 10 & 0,067 \\
\hline $\begin{array}{l}\text { Basılı } \\
\text { Evrak }\end{array}$ & 5 & 5 & 25 & 10 & 5 & 5 & 0,091 \\
\hline Toplam & 100 & 100 & 100 & 100 & 100 & 100 & 1,000 \\
\hline
\end{tabular}


Tablo 5'te ön büro- danışmanlık hizmetlerinin ait alt parçalarının göre önem dereceleri ifade edilmektedir. Konaklama işletmelerinin ürün/hizmet üretiminin emek yoğun olarak gerçekleşmektedir. Bu nedenle konaklama işletmelerinde personel giderleri işletmenin önemli maliyet kalemini oluşturmaktadır. Ön büro- danışmanlık hizmetlerinin de emek yoğun olarak faaliyet gösterdiğinden personel parçasına ait giderlerin diğer maliyetlere oranı oldukça fazladır.

Tablo 6'da kat hizmetleri-konaklama (oda) alt parçalarının fonksiyonlarına görece önem dereceleri ifade edilmektedir. Kat hizmetleri -konaklama (oda) bölümünde de personel maliyetlerinin diğer parçalara oranla daha fazla olmasının sebebi yine emek yoğun hizmet sunmasından kaynaklanmaktadır.

Tablo 6. Kat Hizmetleri Alt Parçalarının Fonksiyonlarına Görece Önem Dereceleri

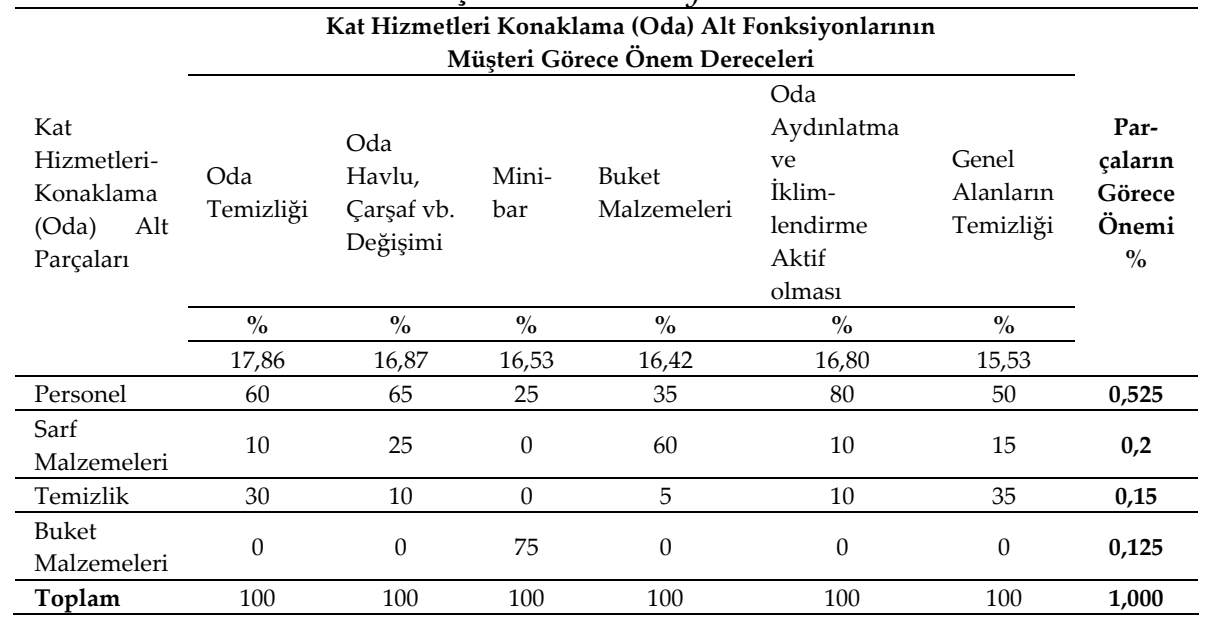

Tablo 7'de yiyecek-içecek hizmetleri alt parçalarının fonksiyonlarına görece önem dereceleri ifade edilmektedir. Konaklama işletmelerinin diğer bölümlerinin aksine, yiyecek- içecek hizmetleri alt parçaları maliyet oranları incelendiğinde hazırlık-alınan malzemeler parçasının diğer parçalara göre daha fazla maliyet unsuru olduğu görülmektedir. 
Tablo 7. Yiyecek-İçecek Hizmetleri Alt Parçalarının Fonksiyonlarına Görece Önem Dereceleri

\begin{tabular}{|c|c|c|c|c|c|c|c|}
\hline \multirow{4}{*}{$\begin{array}{l}\text { Yiyecek- } \\
\text { İçecek Alt } \\
\text { Parçaları }\end{array}$} & \multicolumn{6}{|c|}{$\begin{array}{l}\text { Yiyecek-İçecek Alt Fonksiyonlarının } \\
\text { Müşteri Görece Önem Dereceleri }\end{array}$} & \multirow{4}{*}{$\begin{array}{r}\text { Par- } \\
\text { çaların } \\
\text { Görece } \\
\text { Önemi } \\
\%\end{array}$} \\
\hline & $\begin{array}{c}\text { Servis } \\
\text { Hızı } \\
\text { ve } \\
\text { Şekli }\end{array}$ & $\begin{array}{l}\text { Çeşitli- } \\
\text { lik }\end{array}$ & $\begin{array}{l}\text { Lezzet } \\
\text { ve } \\
\text { Kalite }\end{array}$ & $\begin{array}{l}\text { Doyurucu- } \\
\text { luk }\end{array}$ & $\begin{array}{l}\text { Hijyen } \\
\text { ve } \\
\text { Temizlik }\end{array}$ & $\begin{array}{l}\text { Sunum } \\
\text { Görsellik }\end{array}$ & \\
\hline & $\%$ & $\%$ & $\%$ & $\%$ & $\%$ & $\%$ & \\
\hline & 17,78 & 16,54 & 16,39 & 16,47 & 16,65 & 16,17 & \\
\hline Personel & 30 & 0 & 40 & 0 & 25 & 35 & 0,217 \\
\hline Pişirme & 30 & 20 & 30 & 40 & 30 & 35 & 0,308 \\
\hline $\begin{array}{l}\text { Hazırlık- } \\
\text { Alınan } \\
\text { Malzemeler }\end{array}$ & 40 & 80 & 30 & 60 & 45 & 30 & 0,475 \\
\hline Toplam & 100 & 100 & 100 & 100 & 100 & 100 & 1,000 \\
\hline
\end{tabular}

\section{Hizmet Parçalarının Hedef Maliyet Endeksleri}

Hizmet parçalarına ait müşteri önem derecesinin her bir parçanın dahil olduğu hizmet parçası içindeki maliyet payına bölünmesi sonucu hizmet parçasının hedef maliyet endeksi hesaplanmaktadır.

\section{Hizmet parçalarının hedef maliyet endeksinin hesaplanmast:}

Parçanın değer endeksi = parçanın müşteri önem derecesi / parçanın maliyet ağırlı̆̆ 1

Hedef maliyet endeksi genellikle 1'den büyük olması arzu edilmektedir. Hedef maliyet endeksi 1'den büyük olduğunda parça maliyeti ucuz; 1 'den küçük olduğunda ise parça maliyeti pahalı olmaktadır. Bu bağlamda, hedef maliyet endeksinin 1'den büyük olması durumunda ürünün yeniden gözden geçirilerek hizmetin fonksiyonelliğini artırmak gerekmektedir. Hedef maliyet endeksinin 1'den küçük olduğu durumlarda ise parça maliyetinin müşteri değer algisından yüksek olduğu olması sebebiyle parça maliyeti müşteriler için pahalı olduğundan maliyet minimizasyonuna gitmesi gerekmektedir (Çolak, 2018, s.231). 
Tablo 8. Hizmet Parçalarının Hedef Maliyet Endeksleri

Ön Büro - Danışmanlık Hizmetleri Parçalarının

Hedef Maliyet Endeksleri

\begin{tabular}{|c|c|c|c|}
\hline Parçalar & $\begin{array}{l}\text { Müşteri Önem } \\
\text { Derecesi }\end{array}$ & $\begin{array}{l}\text { Maliyet } \\
\text { Ağırlığ1 }\end{array}$ & Maliyet Endeksi \\
\hline Personel & 0,842 & 0,70 & 1,203 \\
\hline Sarf Malzemeleri & 0,067 & 0,24 & 0,280 \\
\hline Basılı Evrak & 0,091 & 0,06 & 1,516 \\
\hline \multicolumn{4}{|c|}{ Kat Hizmetleri- Konaklama (Oda) Parçalarının Hedef Maliyet Endeksleri } \\
\hline Parçalar & $\begin{array}{l}\text { Müşteri Önem } \\
\text { Derecesi }\end{array}$ & $\begin{array}{l}\text { Maliyet } \\
\text { Ağırlığ }\end{array}$ & Maliyet Endeksi \\
\hline Personel & 0,525 & 0,536 & 0,980 \\
\hline Sarf Malzemeleri & 0,200 & 0,321 & 0,623 \\
\hline Temizlik & 0,150 & 0,107 & 1,401 \\
\hline Buket Malzemeleri & 0,125 & 0,036 & 3,472 \\
\hline \multicolumn{4}{|c|}{ Yiyecek-İçecek Parçalarının Hedef Maliyet Endeksleri } \\
\hline Parçalar & $\begin{array}{l}\text { Müşteri Önem } \\
\text { Derecesi }\end{array}$ & $\begin{array}{l}\text { Maliyet } \\
\text { Ağırlığ1 }\end{array}$ & Maliyet Endeksi \\
\hline Personel & 0,842 & 0,615 & 1,370 \\
\hline Pişirme & 0,067 & 0,077 & 0,870 \\
\hline $\begin{array}{l}\text { Hazırlık-Alınan } \\
\text { Malzemeler }\end{array}$ & 0,091 & 0,308 & 0,295 \\
\hline
\end{tabular}

Tablo 8'de gösterilen hizmet parçalarının hedef maliyet endekslerinin hesaplama yöntemi ön büro-danışmanlık hizmetlerinin alt parçaları üzerinde aşağıda belirtildiği gibi uygulanmaktadır.

Ön büro hizmetleri personel parçası hedef maliyet endeksi $=0,842$ / 0,70 $=1,203$

Ön büro hizmetleri sarf malzemeleri parçası hedef maliyet endeksi $=0,067$ $/ 0,24=0,280$

Ön büro hizmetleri basılı evrak parçası hedef maliyet endeksi $=0,091$ / 0,06 $=1,516$

\section{Sonuç ve Öneriler}

Küreselleşmenin getirdiği rekabet ortamında işletmeler rakiplerine karşı rekabet avantajı elde etmek, pazar payını artırmak, varlıklarını sürdürebilmek ve hissedarlarının arzuladıkları karlılık düzeyine ulaşabilmek için müşterilerine sunmuş olduğu ürün ve hizmetin kalitesini artırmak, 
maliyetlerini minimize etmek ve müşteri beklentisini karşılayan kalite-fiyat dengesini sağlayarak faaliyetlerini gerçekleştirmeleri gerekmektedir. Diğer sektörlerdeki işletmeler gibi turizm sektöründe yer alan konaklama işletmeleri de geçerliliğini yitirmeye başlayan geleneksel maliyetleme yöntemi olarak maliyet+kâr anlayışından ayrılarak süreci başarıyla tamamlamak adına tüm değişkenleri dikkate alan hedef maliyetleme sistemini kullanmaktadır.

Çalışma kapsamında yapılan hesaplamalar sunucunda oluşan bulgulara göre; ön büro-danışmanlık hizmetleri sarf malzemeleri parçasının; kat hizmetleri-konaklama (oda) personel ve sarf malzemeleri parçalarının; yiyecek-içecek hizmetleri pişirme ve hazırlık-alınan malzemeler parçalarının hedef maliyet endeksi 1'den küçük çıkmıştır. Elde edilen bu bulgulara göre konaklama işletmesinin belirtilen hizmet parçalarının üretimi aşamasında müşterinin algıladığ 1 değerden daha fazla maliyete katlanmakta ve bu nedenle söz konusu parçalarda maliyet azaltmaya yönelik planlamaların yapılması gerekmektedir. Konaklama işletmesinin hizmet parçalarında hedef maliyet endeksi 1'den büyük olduğu; ön bürodanışmanlık hizmetleri personel ve basılı evrak parçalarında; kat hizmetleri-konaklama (oda) temizlik ve buket malzemeleri parçalarında; yiyecek-içecek hizmetleri personel parçasında işletme maliyetleri sabit tutarak sunulan ürün ve hizmetin fonksiyonelliğini artırması gerekmektedir.

Konaklama işletmesinin hedef maliyetleme endeksinin 1'den küçük olan parçalarda işletmenin ürün ve hizmeti üretmek için katlandığı maliyete oranla müşterinin daha az değer verdiği hizmetlerde maliyetlerin azaltılmasını sağlamaya yönelik olarak uygulanması gereken öneriler;

- Konaklama işletmesinin dışardan satın aldığı ürün ve hizmetleri daha uygun fiyatla işletmeye kazandırması adına piyasa araştırmalarında bulunarak işletmenin satın alama maliyetlerini minimuma indirilmesi için gerekli girişimde bulunulmalıdır.

- Menü oluşturulurken mevsimsel ürünlere yer verererek arz edilen ürünün edinim maliyetlerinin azaltılması sağlanmalıdır.

- İhtiyaç duyulan malzemeler stok devir hızı göz önünde bulundurularak mevsiminde düşük maliyetle tedarik edilmeli ve uygun depolama koşullarında stoklanlamılıdır. 
- Sarf malzemesi kullanımının azaltılmasına yönelik önlemler alınmalıdır. Örneğin; odalarda kullanılan sıvı sabun ve şampuan gramajları gözden geçirlerek optimum seviyenin belirlenip israfın önüne geçilmelidir.

- Sarf malzemesi alımı ile ilgili tedarikçi firmalardan kaliteden ödün vermeden daha düşük maliyetli ürünleri tercih edilmelidir.

- Yiyecek içecek bölümlerinde kullanılan malzemelerin dışarıdan tedarik edilmesinin maliyeti işletme bünyesinde üretilmesinden daha fazla ise işletme idaresince karşılanmasına gidilmelidir. Örneğin; ekmek ihtiyacının dişardaki işletmelerden karşılanması yerine işletme bünyesinde bulunan pastane bölümünden karşılanması.

- Yiyecek-içeceklerin hazırlanmasında daha az enerji tüketimi yapan fırın ve ocaklar kullanılarak enerji tüketimi azaltılmalıdır.

- Sarf malzemelerinin kullanımını azaltmak için ortak kullanım alanındaki lavabolarda kâğıt havlu yerine kurutma cihazlarının kullanımını artırılmalıdır.

- Konaklama işletmesinin hedef maliyetleme endeksinin 1'den büyük olan parçalarda müşteri değer algısı dikkate alınarak ürün ve hizmetlerin fonksiyonelliğini artırmaya yönelik olarak yapılması gerekenler;

- Personellerin alanı ile ilgili gerekli eğitmin alması sağlanarak hizmet kalitesinin artırılması sağlanmalıdır.

- İşletme sunmuş olduğu hizmetini kalitesini artırarak müşteri mumnuniyeti sağlamak için ihtiyaç duyulan alanlarda bilgi teknolojilerinin kullanımı yaygınlaştırmalıdır. Örneğin; konaklama işletmelerinde online revervasyon sistemi kullanılması sonucu; müşterilerden kenidisine ait istenen bilgileri revervasyon aşamasında sisteme işleyerek otele giriş işlemi için resepsiyondaki bekleme süresini en aza indirilmesi.

- Müşterilerin otel hizmetleri hakkında bilgi sahibi olmaları için müşteriler tarafından yaygın olarak kullanılan ortak alanlarda bilgilendirme panoları oluşturulmalı ve otel tanıtım videoları ortak kullanım alanlarında alıcıya hem görsel hem de sesli olarak iletilmesi sağlanmalıdr. 
Sonuç olarak, konaklama işletmelerinde geleneksel maliyet yöntemlerinin yerine yaygın olarak kullanılmaya başlanan hedef maliyet yöntemi çağın gereklerine uyum sağlayan modern yöntemdir. Hedef maliyet yönteminin kalifiye personel tarafından uygulanması halinde; yöneticilere stratejik karar alma sürecinde bilgiye erişimde ve güvenilir bir yol sunacaktır. İşletme yöneticileri tarafından hedef maliyet yöntemi uygulanmasında müşteri değer algısının dikkate alınması gereken faktörler arasındadır. Müşteri değer algısını sürece dahil eden konaklama işletmeleri yöneticiler bunun sonucunda; müşteri memnuniyet düzeyinin artırılmasını ve müşteri sadakatini oluşmasını temin ederek işletme karlılık oranına katkı sağlayacaktır. İşletme hizmet parçalarında maliyet optimizasyonunu sağlanması için müşteri nezdinde diğer hizmetlere göre önem görecesi daha düşük olan hizmetlerin maliyetlerin azaltılmasına gidilmesi gerekmekte olup tersi durumlar da ise müşteri nezdinde değerli olan hizmetlerin işletme yönetimi tarafından dikkate alınarak hizmet kalitesinin artırılmasına gidilmesi gerekmektedir. 
EXTENDED ABSTRACT

\title{
Investigation of the Relationship Between the Value Perception of Customer and Target Cost: Sample of A Hotel Management
}

\author{
Nilgün Sanalan Bilici - Volkan Tuncel \\ Atatürk University-Bingöl University
}

In today's competitive environment where the sale price is determined by the market, businesses need to achieve a minimum level of costs, which is the most important thing they can change in order to sustain their assets successfully and increase their profitability. With this point of view, managing customer perception of value is important in achieving the objectives of the management. In this context, instead of the inadequate traditional cost method, the target cost method is applied, which enables the management of the costs that will meet the customer demands and expectations.

With the global market as a whole, traditional marketing has been replaced by customer-oriented marketing. As in other sectors, businesses in the tourism sector are applying strategies to meet customer expectations in order to get more shares from the global market. The customers who purchase the product and service offered by the businesses for a certain fee, the customer value is obtained as a result of the comparison of the money he has paid with the product and service he has purchased. Businesses should determine customer value both to ensure customer satisfaction and to improve service quality. The findings obtained should be analyzed and initiatives should be taken to increase the perception of customer value regarding the product and service offered.

Today, businesses implement different strategies to increase their profitability and reduce costs. In order to increase operating profitability, managers use more modern methods instead of traditional profit + cost method in determining the price of goods and services. One of the widely used new method models is the target costing method. With the target 
costing method, businesses can determine the customer value by comparing the experience gained by the customers and the costs incurred. In order to ensure their sustainability, businesses should consider customer value at every stage of production. Businesses that can successfully implement target costing management by the business manager will gain superiority over their competitors by increasing the profitability rate. Therefore, application of target costing method is important for enterprises.

The aim of the study is to contribute to the accommodation managers in terms of their managerial decisions to ensure the satisfaction of business shareholders and customers by examining the relationship between customer value perception and target cost in accommodation establishments. For this purpose; a survey prepared for the customers of an accommodation company operating in Ardahan was applied and 363 customers were interviewed by using face to face interview technique.

Within the scope of the findings, firstly the information obtained from the business management was evaluated. Subsequently, the significance level of the sub-dimensions of the service for determining customer value was calculated. After calculating the significance level of the sub-dimensions of the service, the target cost indices of the sub-dimensions were calculated. Thus, it can be possible to the findings obtained how to take measures in parts where target cost indices were calculated.

According to the findings obtained in the calculations made in the scope of the study; Front desk consulting services consumables, housekeeping-accommodation (room) personnel and consumables and food and beverage services for cooking and preparation materials received target cost index is less than 1 . Therefore, the accommodation business incurs more cost than customer value during the production of the specified service parts. So plans should be made to reduce the cost of these parts. In order to ensure that the target cost index in the service parts of the accommodation business is greater than 1, the personnel costs of Front desk consulting services and printed documents, housekeeping-accommodation (room) cleaning and bouquet materials and food and beverage services must be kept constant and functionality in the product and service offered they should be increased.

According to the results of the research; In order to reach the target cost level, the accommodation business should incorporate customer's value 
perception into target costing process. In this regard, in order to reach the level of profitability targeted by the enterprise, it was determined which costs would be lowered and which service parts should improve functionality.

If the target cost method is applied by qualified personnel, managers are provided with a reliable way to access information in the strategic decision-making process. Customer value is one of the factors to be taken into consideration in the application of target cost method by business managers. If managers incorporate customer value into the process, it enables customer satisfaction and customer loyalty to occur and contributes to business profitability.

\section{Kaynakça / References}

Acar, D. ve Şenol, H. (2014). Konaklama işletmelerinde hedef maliyetleme uygulama düzeylerinin tespitine yönelik araştırma. Süleyman Demirel Üniversitesi Sosyal Bilimler Enstitüsü Dergisi, 2(20), 1-25.

Alagöz, A., Yılmaz, B.ve Ay, M. (2005). Üretim maliyetlerinin düşürülmesinde hedef maliyetleme yönteminin rolü ve uygulanabildiğine yönelik bir araştırma. V. Ulusal Üretim Araştırmaları Sempozyumu, İstanbul Ticaret Üniversitesi, 25-27 Kasım 2005, İstanbul.

Alpkan, S. (2012). Turizm işletmelerinde stratejik maliyet yönetim aracı olarak hedef maliyetleme ve uygulama örneği. Yüksek Lisans Tezi Karabük Üniversitesi Sosyal Bilimler Enstitüsü, Karabük.

Altunel, M.C. ve Günlü, E. (2015). Deneyimleme kalitesi, algılanan değer ve memnuniyetin müze ziyaretçilerinin tavsiye etme eğilimi üzerindeki etkisi. Anatolia: Turizm Araştırmaları Dergisi, 26 (2), 191206.

Akkaya, F.A. (2010). Hedef maliyetleme yönetiminin konaklama işletmelerinde uygulanabilirliğinin değerlendirilmesi ve bir turizm işletmesinde uygulama. Yüksek Lisans Tezi, Dumlupınar Üniversitesi Sosyal Bilimler Enstitüsü, Kütahya.

Aksoylu, S. ve Dursun, Y. (2001). Pazarda rekabetçi üstünlük aracı olarak hedef maliyetleme. Sosyal Bilimler Enstitüsü Dergisi, 11, 357-371.

Andersen, A. (1998). Tools and techniques for implementing target costing, USA: IMA Institute of Management Accountants Publishing. 
Ansari, S. Bell, J. ve Okano, H. (2007). Handbook of management accountign research, In Target Costing: Uncharted Research Territory (p.513), Amsterdam: Elsevier Yayıncilik

Ceran, Y. ve Özdemir, Ş. (2013). Sağlık işletmelerinde paket işlem fiyat uygulamasının hedef maliyetleme yöntemi ve stratejik pazarlama muhasebesi açısından değerlendirilmesi ve özel $x$ diyaliz merkezinde bir uygulama. Selçuk Üniversitesi İktisadi ve İdari Bilimler Fakültesi Sosyal ve Ekonomik Araştırmalar Dergisi, 26, 450-478.

Çakır, Ş. (2018). Kaizen maliyetlemenin maliyet etkinliği açısından incelenmesi: Konaklama işletmesi örneği, Yüksek Lisans Tezi, Karabük Üniversitesi Sosyal Bilimler Enstitüsü, Karabük.

Çetin, A. ve Atmaca, M. (2009). Hedef ve standart maliyetleme sistemleri'nin karşılaştırmalı olarak incelenmesi, Marmara Üniversitesi İktisadi ve İdari Bilimler Fakültesi Dergisi, 26 (1), 313-329.

Çetintürk, İ. (2017). Müşteri değeri, müşteri tatmini ve marka sadakati: üniversite sosyal tesisleri üzerine bir araştırma, Seyahat ve Otel İşletmeciliği Dergisi, 14, 93-109.

Çolak, O. (2018). Her şey dâhil sistemde fiyat duyarllık ölçümü ve kalite maliyetleri yönetiminin hedef maliyetleme sürecine entegrasyonu: bir otel işletmesinde uygulama. Doktora Tezi, Mersin Üniversitesi Sosyal Bilimler Enstitüsü, Mersin.

Erk, Ç. (2009). Müşteri için değer yaratma, müşteri sadakati oluşum süreci ve şirket performansina etkileri üzerine araştırma. Trakya Üniversitesi Sosyal Bilimler Enstitüsü, Yüksek Lisans Tezi, Edirne.

Işık, I. ve Yılmaz, B.B. (2016). Konaklama işletmelerinde yiyecek içecek maliyet kontrolü: Bir otel işletmesinin yiyecek içecek maliyet kontrol yöntemleri üzerine inceleme. Girişimcilik ve Kalkınma Dergisi, 11, 60-83.

Geçgin, E. (2013). Hedef maliyetleme sisteminin menü analizinde kullanılması: Bir yiyecek içecek işletmesinde yapılan uygulama ve sonuçlar", Yüksek Lisans Tezi, Mersin Üniversitesi Sosyal Bilimler Enstitüsü, Mersin. Güler, E.G. (2009). Otel işletmelerinde değer yaratma ve müşteri değeri algılaması üzerine bir araştırma: Edirne'deki oteller örneği. Anatolia: Turizm Araştırmaları Dergisi, 20(1), 61-76.

Karahan, M. (2018). Hedef maliyetleme: Halı işletmesinde bir uygulama, Elektronik Sosyal Bilimler Dergisi, 17(65), 362-378. 
Kaya, C. T. (2013). Hedef maliyetleme sistemiyle kaizen ve yaşam çevrim maliyetleri arasındaki çapraz ilişkiler. Muhasebe Bilim Dünyası Dergisi (MÖDAV), 15 (4), 135-154.

Kaya, G. A. (2010). Hedef maliyetleme. Firat Üniversitesi Sosyal Bilimler Dergisi, 20(1), 313-332.

Kutay, N. ve Akkaya, G.C. (2000). Stratejik maliyet yöntemi olarak hedef maliyetleme. Dokuz Eylül Üniversitesi İktisadi ve İdari Bilimler Fakültesi Dergisi, 15 (2), 1-15.

Macit, A. (2018). Hava kargo işletmelerinde Kaizen maliyetleme ve uygulamaları. Yüksek Lisans Tezi, Kocaeli Üniversitesi Sosyal Bilimler Enstitüsü, Kocaeli.

Okutmuş, E. ve Ergül, A. (2013). Konaklama işletmelerinin yiyecek içecek faaliyetlerinde tedarik zinciri maliyetlerinin hedef maliyetleme ile birlikte uygulanmas1. Journal of Yasar University, 8(32), 5409-5432.

Okutmuş, E. ve Ergül, A. (2015). Konaklama işletmelerinde hedef maliyetleme, değer analizi ve Kaizen maliyetleme yöntemlerinin birlikte uygulanabilirliğine ilişkin bir araştırma, Muhasebe ve Finansman Dergisi, 65, 97-116.

Oliver, R L. (2015). Satisfaction: A behavioral perspective on the consumer ( $2^{\text {nd }}$ Edition). New York: Routledge.

Öğünç, H. (2010). Hedef maliyetleme sisteminin mermer sektöründe uygulanması, Yüksek Lisans Tezi, Süleyman Demirel Üniversitesi Sosyal Bilimler Enstitüsü, Isparta.

Terzi, A. (2017). Hedef maliyetleme, değer mühendisliği ve Kaizen maliyetleme üçlüsünün çay işletmelerinde birlikte uygulanabilirliği, Researchgate, 7(2), 221-247.

Ural, T. (2008). Değer temelli fiyatlama: Ürünün tüketici değer algısına göre fiyatlanması. Anadolu Üniversitesi Sosyal Bilimler Dergisi, 8(2), $1-16$.

Yıldız, B. ve Çiğdem, Ş. (2018). Havayolu hizmet kalitesinin müşteri memnuniyeti üzerindeki yapısal eşitlik modeli ile analizi, Bingöl Üniversitesi Sosyal Bilimler Enstitüsü Dergisi, 8 (16). 


\section{Kaynakça Bilgisi / Citation Information}

Bilici, S. N. ve Tuncel, V. (2019). Müşteri değer algısı ile hedef maliyet arasındaki ilişkinin incelenmesi: Bir otel işletmesi örneği. OPUSUluslararası Toplum Araştırmaları Dergisi, 11(18), 1408-1436. DOI: 10.26466/opus.554110 